Ritrýnd grein birt 27. ágúst 2018

\title{
Kyngervi kennara í augum foreldra: Mótsagnakenndar kröfur
}

\author{
Maríanna Jónsdóttir Maríudóttir og Ingólfur Ásgeir Jóhannesson
}

\author{
- Abstract $\quad$ Um höfundana $\quad$ About the authors $>$ Heimildir
}

Í greininni er fjallað um viðhorf foreldra til kyngervis grunnskólakennara. Rannsóknin fólst í viðtölum við tíu foreldra, fjóra karla og sex konur, sem áttu bæði dreng og stúlku í grunnskóla, og var að minnsta kosti eitt barnanna á yngsta stigi og annað á miðstigi grunnskólans pegar viðtölin voru tekin. Viðmælendur voru spurðir um afstöðu sína til kyns og kyngervis kennara, karlmennsku, kvenleika, virðingar, aga og umhyggju - allt í pví augnamiði að fá vitneskju um hvort og á hvaða hátt pessi viðhorf væru kynjuð. Viðtölin voru greind í tveimur meginprepum. Á fyrra prepi voru greind nokkur pemu, svo sem karlmennska og kvenleiki; kennarar sem fyrirmyndir og virðing, agi og umhyggja. Við ítarlegri skoðun var bersýnilegt að viðhorf foreldranna voru lituð af einstaklingshyggju og eðlishyggju. Jafnframt komu í ljós ekki einungis ólíkar skoðanir meðal viðmælenda heldur mótsagnir í viðhorfum. Áhersla viðmælenda á einstaklingsmun er mjög líklega til marks um frekar almennan, ef ekki lítinn, skilning á pýðingu kynjajafnréttismála fyrir skólastarfið. Höfundar vilja árétta pað að ef sérstakur vilji er fyrir hendi til að fjölga körlum í grunnskólakennslu, umfram pað að mennta parf fjölda bæði karla og kvenna til starfsins, verður að forðast að gera pað á forsendum sem byggjast á staðalmyndum og hefðbundnum kynhlutverkum. Í kennaramenntuninni parf að undirbúa kennaranema af öllum kynjum undir allar hliðar starfsins. Par á meðal að peir geti sem nýbrautskráđir kennarar vænst pess að stundum verði gerðar til peirra ólíkar kröfur eftir kyni af aðilum innan og utan skólans.

Efnisorð: Kyn kennara, grunnskólakennarar, viðhorf foreldra, staðalmyndir, hlutverk kennara.

\section{Inngangur}

Talsvert umræða hefur verið um kyn og kyngervi kennara á síðustu árum. Eitt af pví sem hefur verið til umræðu er kynjahalli út frá fjölda kennara. Árið 2004 var heildarfjöldi kennara í grunnskólum með kennsluréttindi til að kenna á pví skólastigi 4.045 og voru karlar í kennslu pá 884 talsins eða tæp 22\%. Árið 2015 hafði grunnskólakennurum með réttindi fjölgað í 4.615 en karlkyns kennurum pó fækkað í 822 og hlutfallið lækkað í 18\% (Hagstofa Íslands, 2015). Dví fer pó fjarri að konur hafi verið í meirihluta alla tíð pví að á fyrri hluta 20. aldar voru kennarar í skyldunámi að mestu karlar og á árunum 1909-1945 var hlutfall brautskráðra kvenna frá Kennaraskóla Íslands á bilinu 35-46\% (Loftur Guttormsson, 2008). [1] 
Í pessu samhengi lék okkur forvitni á pví að fá vitneskju um viðhorf foreldra til kyns kennara. Ĺklegt er að pau viðhorf skipti máli, bæði í samfélagsumræðu og pegar kemur að sýn kennara á sjálfa sig (Brody, 2014; Hjalmarsson og Löfdahl, 2014; Ingólfur Ásgeir Jóhannesson, 2004; Sargent, 2000). Í greininni er fjallað um niðurstöður viðtalsrannsóknar um viðhorf foreldra til kyns og kyngervis grunnskólakennara.

Munurinn á orðunum kyn og kyngervi pvælist fyrir peim sem ekki eru handgengnir femínískum hugtakaforða. Hugtakið kyn er notað um líffræðilegt kyn (e. sex). Hugtakið kyngervi (e. gender) vísar til pess ,gervis“ sem fólk tekur á sig við að vera karlar eða konur, eða drengir eða stúlkur. Petta er pað gervi sem hið líffræðilega kyn (e. sex) tekur á sig í samskiptum í samfélaginu. En pótt kyn vísi til líffræðilegs kyns er pað orð yfirleitt notað í almennri umræðu og iðulega í fræðilegri umræðu í tilvikum par sem kyngervi er útlistað á nákvæmari hátt.

\section{Eðlishyggjan í orðræðunni}

Í umræðunni um kyn og kyngervi takast á tvenns konar sjónarmið; annað peirra byggist á eðlishyggju en hitt er kennt við mótunarhyggju. Eðlishyggjan felst í pví að gert er ráð fyrir að kynin - karlar og konur - séu í eðli sínu ólík. Par er alhæft um eiginleika fólks af sama kyni, oftar en ekki út frá staðalmyndum um kynhlutverk kynjanna. Með mótunarhyggju er pví hafnað að ólík hlutverk, staða og hegðun kynjanna séu meðfæedd fyrirbæri. Deir sem aðhyllast mótunarhyggju halda pví fram að hugmyndir okkar um kvenleika og karlmennsku séu félagslega mótaðar og hvað teljist karlmennska og kvenleiki fari eftir aðstæðum hverju sinni (sjá til dæmis Ingólf Ásgeir Jóhannesson, 2004; Skelton, 2012).

Karlmennska og kvenleiki eru lykilhugtök í umræðum um kyngervi. Connell (2006) heldur pví fram að með pví að tala um karlmennsku og kvenleika sé verið að vísa til peirra eiginleika sem samfélagið hefur eignað körlum og konum. Vandinn við petta er pó kannski ekki sá að eigna kynjum ólíka eiginleika heldur að karlmennsku og kvenleika er iðulega stillt upp sem andhverfum með ólíkt vægi par sem hið karllæga er yfirskipað hinu kvenlæga (Ingólfur Ásgeir Jóhannesson, 2004; Dórdís Dórðardóttir, 2005, 2012). Viðteknar hugmyndir um karlmennsku tengjast oft pví að vera sterkur og stór, að sýna hetjuskap, vera ekki stelpulegur og vera leiðtogi (Guðný Guðbjörnsdóttir, 2007) og síðast en ekki síst á karlinn að sýna að hann sé gagnkynhneigður (Connell, 2006; Ingólfur Ásgeir Jóhannesson, 2004). Đó hefur hinn „,mjúki maður“ verið nefndur til sögunnar en hann er í góðum tengslum við tilfinningar sínar, ljúfur og yfirleitt í góðu sambandi við móður sína (Goddard, 2000). Hugmyndin um mjúka manninn er pó líka til marks um eðlishyggju sem felst í tiltekinni staðalmynd sem karlinn parf að uppfylla.

En pað eru til flóknari ímyndir um karlmennsku byggðar á skilningi mótunarhyggju, til dæmis hugmyndir um umhyggjukarlmennsku (e. caring masculinities) (Elliott, 2016) og inngildandi karlmennsku (e. inclusive masculinities). Slíkar hugmyndir fela í sér pað sjónarmið að hefðbundnar og íhaldssamar tegundir af karlmennsku séu að missa eða muni missa gildi sitt gagnvart peim „mýkri“ sem áđur hafa verið undirskipaðar eða jaðarsettar (Anderson, 2009; Dórdís Dórðardóttir, 2012). Í bæði umhyggjukarlmennsku og inngildandi karlmennsku felast pær hugmyndir að karlmennska geti verið margs konar án pess að slegið sé af kröfunni um að karlinn sé „raunverulegur" karl. Á ensku er gjarnan notuð fleirtala af orðinu karlmennska (e. masculinities) til að tákna fjölbreytileika og baráttuna um pað hvernig karl má eða á að vera.

Hugmyndir um kvenleika hafa einnig breyst úr pví að vera tengdar fyrst og fremst við eitthvað fíngert og undirskipað yfir í fjölbreytilegri ímyndir (sjá til dæmis Dórdísi Dórðardóttur, 2012). Ástæðan fyrir pví er líklega breytt staða kvenna í samfélaginu par sem pær hafa með kvennabaráttunni haslað sér völl á ýmsum vettvangi sem karlar voru áđur einir á. Prýstings verður pó vart á nútímakonur að pær haldi sig við hefðbundin hlutverk kvenna, til dæmis að sjá um heimili og börn, um leið og pær taka að sér störf utan heimilis (Martino og Lauriano, 2013). Detta má kalla hugmynd um „ofurkonu“. Ofurkonuhugtakið vísar til kvenna sem leitast við að ,geta allt" og 
eftir pví sem vald kvenna eykst hefur pað færst í vöxt að konur upplifi sig í aðstæðum par sem pær reyna að halda slíkri ímynd ofurkonunnar á lofti (Martino og Lauriano, 2013). Okkur sýnist ofurkonuhugmyndin pó vera byggð á eðlishyggju. Hugmyndir Schippers (2007) um mengandi kvenleika (e. emphasized femininity) eru af öðrum toga. Đær byggjast á pví að konur nái að „menga“ valdasambandið milli karla og kvenna sem felst í undirskipun hins kvenlæga. Mengandi kvenleiki snýst um að kona sýni myndugleika, taki málin í sínar hendur og sé óhlýðin, eins og Gyða Margrét Pétursdóttir (2012) lýsir pví.

Viðteknar hugmyndir um karlmennsku og kvenleika eru byggðar á hugmyndum um sérstakt eðli kynja. Nýrri hugmyndir um karlmennsku og kvenleika, og um að „eðli“ karla og kvenna geti breyst, kunna að vera til marks um mótunarhyggju. Engu að síður er eðlishyggjan, par sem körlum og konum og drengjum og stúlkum er ætlað tiltekið eðli, mjög sterk. Í samræmi við hana hafa mótast viðteknar hugmyndir um fyrirmyndir sem eins konar kynhlutverk (Connell og Messerschmidt, 2005; Ingólfur Ásgeir Jóhannesson, 2004, 2006), sem hafa haft mikil áhrif á orðræðuna í samfélaginu og á umræðuna um kyn kennara.

\section{Kennslukarlar og kennslukonur}

Grunnskólakennarastarfið gerir faglegar kröfur af margvíslegum toga. Oft er pessum kröfum skipt í tvennt, annars vegar um pekkingu í kennslugrein og hins vegar í kennslufræði sem felur pá einnig í sér hæfnina til að koma námsefni til skila (Ingólfur Ásgeir Jóhannesson, 1992). En starf nútímagrunnskólakennara er miklu flóknara en svo að tvær breytur, pekking á kennslugrein og hæfnin til að koma námsefni til skila, dugi til að lýsa pví. Grunnskólakennarar sinna margvíslegum öðrum verkefnum sem fela í sér umhyggju fyrir nemendunum (sjá til dæmis Hjalmarsson og Löfdahl, 2014). Ingólfur Ásgeir Jóhannesson (2004) leggur áherslu á að umhyggja sé faglegt gildi og að kennarar, bæði kennslukarlar og kennslukonur, purfi að búa yfir vinnubrögðum sem umhyggjan krefur pau um. Sama gildir um aga; kennararnir purfa að kunna fagleg vinnubrögð til að nemendum líði vel í kennslustofunum. Pá purfa grunnskólakennarar að geta sinnt ólíkum hópum nemenda: drengjum og stúlkum, nemendum af ólíkum félagslegum og menningarlegum uppruna, og nemendum sem hafa margvíslegar og ólíkar sérparfir. Detta merkir að peir purfa að pekkja félagslegan bakgrunn margra hópa í samfélaginu og staðalmyndir sem samfélagið skapar, til dæmis af drengjum og stúlkum.

Hér vandast málið pví pað hefur verið tilhneiging í orðræðunni um skólastarfið að tengja umhyggju og aga við kyn kennaranna. Warin og Gannerud (2014) benda á að lengi hafi verið litið á umhyggju sem eðlislægan eiginleika kvenna og pví verið litið svo á að pær séu betur til pess fallnar en karlar að kenna ungum börnum. Degar litið er á agann, pá benda niðurstöður Brodys (2014), sem talaði við sex kennslukarla frá ólíkum löndum, og Ashcraft og Seviers (2006), sem tóku viðtöl við 14 kennslukarla í grunnskólum í Bandaríkjunum, til pess að peir telji að peir haldi uppi betri aga en kennslukonur. Að kyn peirra hafi par úrslitaáhrif. Burn og Pratt-Adams (2015) halda pví fram að dýpri rödd karla og meintir líkamlegir yfirburðir geti verið áhrifavaldur pegar kemur að virðingu nemenda fyrir kennurum. Niðurstöður Ingólfs Ásgeirs Jóhannessonar (2004), sem ræddi við kennslukonur í íslenskum grunnskólum, gefa vísbendingar um að pessi orðræða um aga kennslukarla hafi pau áhrif að sumir drengir taki síður mark á kvenkyns kennurum en körlum. Nútímakennslukarlar mæta aftur á móti peirri pversögn að á meðan starf grunnskólakennara felst, meðal annars, í umhyggju gagnvart nemendum pá sé oft æetlast til að peir sýni hefðbundna karlmennsku byggða á styrk - í beinni mótsögn við pá faglegu kröfu að sýna umhyggju (Ashcraft og Sevier, 2006).

Eðlishyggjusjónarmið virðast vera mjög fyrirferðarmikil í orðræðu um að pað sé vandamál hversu fáir karlar séu kennarar í leik- og grunnskólum. Í skýrslunni Menntun fyrir alla, sem er yfirlýsing sett fram á alpjóðaráðstefnu UNESCO í Dakar í Senegal árið 2000, er meðal annars tekið fram að auka purfi hlutfall karla í grunnskólum en ekki er tekið skýrt fram hvers vegna 
(Menntamálaráđuneytið, 2002). Wernersson (2016) telur að prjár helstu ástæðurnar, sem nefndar hafi verið fyrir pví að fjölga purfi kennslukörlum, séu að pað vanti karla sem fyrirmyndir, fjölgun karla myndi bæta atvinnuumhverfi kennarastarfsins og loks almenn jafnréttissjónarmið. Fyrstnefnda sjónarmiðið er tvímælalaust til marks um eðlishyggju meðan pau tvö síðarnefndu eru mun „saklausari“. Dau má túlka pannig að stefnt sé að aukinni fjölbreytni í hópi starfsfólksins í hverjum skóla fremur en að verið sé að hampa körlum.

Kennslukarlar virðast oft mæta væntingum í starfi sínu um að vera karlmennskufyrirmyndir fyrir nemendur, pá einna helst fyrir drengina (Burn og Pratt-Adams, 2015; Sargent, 2000). Rannsóknir styðja pó ekki hugmyndina um að fjölgun peirra sem karlmennskufyrirmynda komi eitthvað sérstaklega til móts við pá drengi sem standa höllum fæti í skólakerfinu (Sternod, 2011). Dvert á móti er pessi hugmynd um karlmennskufyrirmynd skaðleg, byggð á eðlishyggjuhugmyndum um kynhlutverk (Ingólfur Ásgeir Jóhannesson, 2006). Á hinn bóginn telur Younger (2016) аð umræða dagsins í dag snúist miklu frekar um viðurkenningu á fjölbreytni einstaklinga í hópi nemenda og kennara og að próa skuli skóla með fjölbreytnina að leiðarljósi.

\section{Rannsóknarspurning}

Rannsóknirnar, sem við höfum vitnað til, benda til pess að gerðar séu margvíslegar kröfur til kennara og stundum ólíkar eftir pví hvort kennarinn er karl eða kona. Við spyrjum pví hver séu viðhorf foreldra til kyngervis kennara, hvers konar sjónarmið ráđa för og hvort og pá hvaða mótsagnir koma fram. Við spyrjum einnig hvort rétt sé að leggja áherslu á að fjölga kennslukörlum og pá á hvaða forsendum.

\section{Aðferð}

Rannsóknin er eigindleg viðtalsrannsókn. Rannsóknaráherslan er femínísk en í slíkum rannsóknum er áhersla lögð á áhrif og mikilvægi kyngervis (Rannveig Traustadóttir, 2013). Í pessu tilviki með pví að kanna hvaða áhrif hugmyndir foreldra um kyngervi og kyn kennara hafa á kröfur peirra til kennaranna og skólanna.

\section{Viðtöl}

Viðmælendur voru alls tíu, fjórir karlar og sex konur, á aldrinum 32-48 ára. Fimm peirra voru búsettir á höfuðborgarsvæðinu en fimm á landsbyggðinni. Viðmælendur voru með fjölbreytta en mislanga menntun og unnu ólík störf. Gögnunum var safnað með samtals átta viðtölum við foreldrana. Í tveimur tilvikum voru hjón saman í viðtali, að eigin ósk, og talað var við tvenn önnur hjón í einstaklingsviðtölunum, í öllum tilvikum voru hjónin karl og kona. Viðmælendurnir fengu dulnefnin Alex, Anna, Elín, Ingi, Jóhann, Klara, Orri, Sóla, Ugla og Vala.

Viðmælendur voru fundnir með hentugleikaúrtaki á prennan hátt: með pví að auglýsa á Facebook, leita til skólastjóra í grunnskólum og í gegnum kunningsskap við fyrri höfund eða vini hennar. Allir viðmælendur áttu bæði dreng og stúlku í grunnskóla og annað eða eitt barnanna var á yngsta stigi og eitt peirra var á miðstigi. Einnig var skilyrði til að falla inn í úrtakið að annað barnið á yngsta eða miðstigi hefði karlkyns umsjónarkennara á meðan viðtölin voru tekin. Samtals voru börn viðmælenda í sex grunnskólum pegar viðtölin voru tekin. Vegna fjarlægðar voru tvö einstaklingsviðtöl tekin í símtali en í öðrum tilvikum lagði rannsakandi land undir fót til að heimsækja viðmælendur. Öll viðtölin nema eitt voru tekin á heimili viðmælendanna.

Forprófun á viðtalsramma, sem höfundar sömdu í sameiningu, fór fram með undirbúningsviðtali í október 2016 og eftir pað voru spurningar lagfærðar. Fyrsta viðtalið var tekið í nóvember 2016 og pau síðustu í desember 2017. Fyrrgreindur höfundur tók viðtölin. Viðmælendur voru meðal annars spurðir um afstöðu sína til kyns og kyngervis kennara og til margra hugtaka sem hafa 
verið í umræðunni um petta efni, pað er karlmennska, kvenleiki, virðing, agi og umhyggja - allt í pví augnamiði að fá vitneskju um hvort og hvernig pessi viðhorf væru kynjuð. Viðtölin voru tekin upp og síðar skráð orðrétt af rannsakandanum. Lengd peirra var frá 43 upp í 63 mínútur.

\section{Greining}

Viðtölin voru greind í tveimur meginprepum. Fyrst voru pau prautlesin til að leita að pemum. Leitað var að hugsanlegum lyklum sem einkenndu gögnin og peir skráðir á viðeigandi stað (Lichtman, 2013). Dá voru gögnin lesin aftur í leit að flokkum sem einkenndu pau og peir einnig skráðir. Upphaflega voru allir hugsanlegir flokkar skráđir og tengdir við pá lykla sem pössuðu við viðeigandi flokk. Pá var farið aftur yfir flokkana, peir teknir út sem ekki voru nógu vel studdir af gögnunum og aðrir lagaðir til eftir pörfum. Að lokum voru pemun próuð úr flokkunum sem endurspegluðu merkingu gagnanna (Lichtman, 2013). Í pessari vinnu komu í ljós skýr pemu: karlmennska og kvenleiki (parna komu fyrir hugtökin ofurkonan og mjúki maðurinn); kennarar sem fyrirmyndir; og virðing, agi og umhyggja. Við ítarlegri skoðun, bæði á pemunum sem komu 1 ljós á fyrri stigum greiningarinnar og út frá gögnunum sjálfum, varð ljóst að viðhorf foreldranna voru lituð af einstaklingshyggju, eðlishyggju og mótsögnum.

\section{Gildi rannsóknarinnar og siðferðilegir pættir}

Viðmælendur byggðu sjónarmið sín einkum á reynslu af níu karlkyns kennurum, sem kenndu í sex grunnskólum á peim tíma sem viðtölin voru tekin, en allir höfðu peir reynslu af miklu fleiri kennslukonum. Viðmælendurnir reyndust vera áhugasamir um rannsóknarefnið og voru viðtölin efnisrík. Að mati höfunda gefa pau pví trúverðuga mynd af sjónarmiðum fjölbreytts hóps foreldra með ólíka menntun og búsetu.

Tímafrekt reyndist að finna viðmælendur og pví pótti rannsakendum peir hafa himin höndum tekið pegar fundust hjón sem voru til í viðtal. Í tveimur tilvikum voru hjónin saman í viðtali. Ekki er hægt að sjá á gögnunum að pað hafi skipt máli. Engu að síður er ekki hægt að útiloka að annað peirra hefði svarað öðruvísi eitt síns liðs, en viðtölin urðu pó hlutfallslega styttri.

Farið hefur verið með upplýsingar, sem aflað var í rannsókninni og voru óviðkomandi rannsóknarefninu, sem trúnaðarmál. Notuð eru dulnefni um viðmælendur, fólk og skóla sem minnst er á í frásögnunum. Viðmælendum var gerð grein fyrir pví í upphafi að rannsóknarniðurstöður yrðu birtar og er pví um upplýst sampykki að ræða.

\section{Niðurstöður}

Við gerum í pessum kafla grein fyrir sjónarmiðum foreldra hvað varðar meginpemun, en pau eru: karlmennska og kvenleiki, kennarar sem fyrirmyndir, og virðing, agi og umhyggja. Í síðari hluta kaflans ræðum við birtingarmynd eðlishyggju og einstaklingshyggju í máli viðmælenda okkar.

\section{Karlmennska og kvenleiki}

Viðmælendur voru spurðir út í skilning sinn á karlmennsku og kvenleika. Deim reyndist erfitt að skilgreina karlmennsku og hikuðu gjarna áður en peir ræddu hugmyndir sínar. Annars vegar bentu peir á hefðbundna karlmennskuímynd. Sóla taldi sig hafa ,ímynd af einhverjum sem er ... fastur fyrir og ábyrgðarfullur“; hún sagðist hafa í huga „traustvekjandi ímynd af ... manni með skegg [sem segði:] „Nú er ég kominn hérna til að redda málunum“.“ En henni fannst miður að hafa pessa ímynd. Elín tók í sama streng pegar hún sagði að karlmaður væri „klár, sniðugur, handlaginn, reddari, samt ... umhyggjusamur en samt verndari ..." Hún tók líka fram að slík 
ímynd væri „örugglega eitthvað úr ævintýrunum“.

Hins vegar kom fram pað sjónarmið að karlmennska væri að breytast, en skiptar skoðanir voru á pví hvort pað væri jákvæett. Jóhanni fannst hin nýja karlmennska vera

dálítið skrítin ... Mér finnst hún vera allt of mjúk ... Баð er svona pínulítið verið að reyna að taka kúlurnar af honum [karlinum] finnst mér, of mikið finnst mér ... En ég veit pað ekki, kvenmenn eru orðnir miklir karlmenn og karlmenn eru orðnir miklir kvenmenn [hlær].

Prátt fyrir fyrri ummæli um staðalmynd karlmennsku fagnaði Elín pví að karlar sýndu óhefðbundna karlmennsku. Nú væru karlar komnir fram á vettvanginn sem kvörtuðu undan pví „hvað karlmennskan hefur sett peim pröngar skorður“ og pakkaði hún femínismanum pað. Orri tók í sama streng og sagðist ekki vera hrifinn af peirri staðalmynd af karlmennskunni sem gjarna birtist í samfélaginu og sagði enn fremur að sér fyndist karlmannlegt að vera „pessi mjúka týpa“.

Pegar kom að pví að ræða kvenleika tengdu viðmælendur hugtakið einkum við tvennt: umhyggju og hlýju annars vegar og hæfileikann til að gera marga hluti í einu hins vegar. Vala sagði að skilningur og hlýja væru eiginleikar sem eignaðir væru konum og að peim væri gjarna ætlað að vera umburðarlyndari en karlar:

Баð er líka alveg ... ofsaleg krafa um ... hlýju og mikinn skilning ... Konur verða að vera umburðarlyndari heldur en karlar.

Sóla sá einnig fyrir sér „mjúka, umhyggjusama týpu“ pegar spurt var um kvenleika en tilgreindi einnig prautseigju sem mikilsverðan eiginleika kvenna.

Orri tengdi kvenleika við móður sína sem „,vann alltaf úti“ og „,faðmar pig og hún gefur pér að borða ... hún er til staðar“. Dótt hann notaði ekki ofurkonuhugtakið tengdi hann kvenleikann engu að síður við pað að kona geri alla hluti jafn vel og hugsi um börnin og heimilið af sama metnaði og starfið.

Ef petta er dregið saman voru flestir viðmælendur, nema helst Jóhann, gagnrýnir á hefðbundna staðalmynd karlmennskunnar og sögðu hana vera að breytast. Viðmælendur höfðu fáskrúðugri viðhorf til kvenleika, flestir tilgreindu umhyggju og hlýju. Ugla taldi reyndar að pað að horfa á karlmennsku og kvenleika væri „,svolítið blörrað ... ég meina, karlar sauma út og karlar prjóna og alls konar, og konur skipta um dekk ..." Engu að síður virðast viðhorfin til karlmennsku og kvenleika nokkuð ljós hjá viðmælendum, hvort sem peir eru hrifnir af meintum breytingum eða ekki.

\section{Kennarar sem fyrirmyndir}

Við spurðum hvort viðmælendur teldu kennara mikilvægar fyrirmyndir og fengum við pví jákvæð svör. Sum svörin tengdust pví að pað skipti máli að pað væru fjölbreyttar fyrirmyndir í skólunum. Anna tengdi hlutverk kennara sem fyrirmynda við menntun peirra, að peir hefðu áhuga á starfinu og að peir næðu að miðla peim áhuga áfram:

Ég held að allir kennarar séu bara góđar fyrirmyndir ... Petta eru einstaklingar sem eru búnir að mennta sig og eru að gera eitthvað sem peir hafa áhuga á og miðla pví áfram.

Við getum kallað petta hugmyndina um kennara sem almenna fyrirmynd, sem ótengd er kyni eða kyngervi. Sóla lýsti pessu á pennan veg: „Mér finnst karlkennarar purfa að búa yfir nákvæmlega sömu eiginleikum eins og kvenkennarar ..." En í næstu andrá tók hún fram að pað væri „bara svo gott að hafa einhvern sem maður getur samsamað sig við“ og átti við að drengir og stúlkur gæetu samsamað sig við eigið kyn. 
Ingi, Klara og Vala voru fylgjandi jafnvægi í kennarahópnum pví pað væri margt annað sem skilgreindi okkur en pað kyn sem við samsömum okkur við. Vala orðaði pað pannig:

Já, pað parf að vera jafnvægi. Já, algjörlega. Fyrirmyndir af báđum kynjum ... við purfum bara að sjá fólk af báđum kynjum eða öllum kynjum í alls konar aðstæðum pví pað er ekki endilega kynið sem ... skilgreinir frammistöðu okkar og getu okkar og annað og við purfum bara að læra pað frá unga aldri.

Viðhorf hennar virðist einkennast af mótunarhyggju, sem var raunar ekki mjög algengt í svörum viðmælenda.

Við spurðum út í karla og konur sem fyrirmyndir og sérstaklega um karlkyns kennara. Fram komu pær skoðanir að kennslukarlar gætu verið jákvæðar jafnt sem neikvæðar fyrirmyndir. Ugla sagðist hafa orðið vör við pað hjá drengjunum sínum að peir litu ólíkt á kennarana eftir pví hvort um karl eða konu væri að ræða og nefndi að nemendur spegluðu sig í kennurum eftir kyni:

Já, ég hef alveg orðið vör við pað hjá mínum strákum í sambandi við fyrirmyndir, eins og Aron var hjá karlkyns kennara í Grænaskóla ... ég held að pað sé alveg mikilvægt að pau geti speglað sig í pví ...

Alex, sem reyndar er kennari sjálfur, sagði:

Maður rekur sig á stráka sem virðast bara hafa umgengist konur og vera aldir upp af konum, og í gegnum skólakerfið líka og vita ekki almennilega hvaða fyrirbæri karlar eru ...

En Alex tengdi petta ekki einungis við karlmennskufyrirmyndir heldur fjölbreytni og sagði: „Ég [held] að pað skipti máli að peir [drengirnir] kynnist sem fjölbreyttustum hópi fólks.“

Hjá mörgum viðmælendum virtust skoðanir á fyrirmyndum vera byggðar á fremur stöðluðum hugmyndum um kyngervi. Pannig taldi Elín mikilvægt að drengir hefðu karlmannlegar fyrirmyndir:

Ég myndi vilja sjá ... að nemendur hefou einhvern tímann í lífinu verið hjá kennurum af báðum kynjum. Bara líka til að fyrirbyggja pað, ef að pað er einhver munur par, pað er kannski líka út af umræðunni í samfélaginu að petta sé hræðilegt að pað séu bara konur út af að pá fái strákarnir ekki ... karlmannlega fyrirmynd ...

Klara tók í sama streng; að pað væri mikilvægt „fyrir bæði kynin en sérstaklega fyrir ... stráka“ að hafa karlkyns kennara.

Í orðum Elínar hér að framan kemur fram að ef til vill sé pað orðræðan í samfélaginu sem geri раð аð verkum аð „karlmannlegar fyrirmyndir“ pyki mikilvægar. Orðræðan er auðvitað margbreytileg. Í henni koma líka fram væntingar um fjölbreytni. Flestir viðmælendur lögðu áherslu á að karlar í kennslu væru mikilvægir til að stuðla að fjölbreytni og jafnvægi innan kennarahópsins frekar en að peirra hlutverk væri að vera karlmennskufyrirmynd fyrir nemendur.

\section{Virðing, agi og umhyggja - kynlægir eða almennir eiginleikar?}

Viðmælendur voru spurðir hvort peir teldu að nemendur bæru meiri virðingu fyrir konum eða körlum og hvort kynjamunur væri á pví hvernig kennarar beittu aga og sýndu umhyggju.

Jóhann taldi að nemendur bæru meiri virðingu fyrir sínu eigin kyni vegna pess að pað væri meiri skilningur á milli, svo sem ,stelpur skilja stelpur betur“. Hann tók pað pó fram að nemendur bæru virðingu fyrir peim kennara sem væri ,sanngjarn og góður“. Elín sagði að sú ,,ímynd sem konur hafa, að vera bara ljúf og góð“ væri varla til pess fallin að vinna virðingu nemenda. Hún 
lagði einnig áherslu á að karlmennskuímyndin væri „líkamlegir yfirburðir“ ... og pví fylgdi „einhvern veginn ... ómeðvituð ... ógn“ en vitanlega ættu slíkir meintir yfirburðir ekki við í „vernduðu skólaumhverfi“. Loks nefndi Elín pá algengu ímynd að rödd karla heyrðist betur en rödd kvenna.

Alex, Ingi og Vala höfnuðu pví pó alveg að kyn kennara hefði áhrif á pað hvort nemendur bæru virðingu fyrir kennurum og hvernig hún birtist. Đau tóku börnin sem dæmi um að ekki væri að finna kynjamun. Sóla gerði pað líka að hluta til og sagði hún að börnin gerðu ekki slíkan kynjamun „fyrr en pau eru orðin miklu eldri, held ég ..."

Agi er eitt af grundvallarpemum í umræðu um skólastarf og voru viðmælendur spurðir hvort munur væri á pví hvernig kennslukarlar og kennslukonur beittu aga. Jóhann taldi að körlum gengi betur að halda aga en konum og að peir væru almennt strangari. Hann sagði að karlar ættu að vera harðir og væru aldir upp pannig:

Ég held að peir [karlar] séu svona betri í pví að vera svolítið strangari að hafa svona meiri aga ... Og karlmaðurinn á að vera harður, pað pýðir ekkert að vera með einhvern aumingjaskap ... peir alast upp pannig ...

Anna var í reynd á svipaðri skoðun; hún sagðist geta ímyndað sér að karlar tækju frekar á málunum án pess að einhver eftirköst yrðu:

Ég er viss um að karlmenn, eða einhvern veginn get ég ímyndað mér að karlmenn séu ekki með eitthvað bullshit. [Deir] taka á málunum og pá er pað búið.

Vala var á öđru máli en Jóhann og Anna og sagði að enginn munur væri á aga karla eða kvenna. Hún sagðist aldrei hafa fundið fyrir slíkum mun hjá kennurum barnanna sinna og að peim hefði almennt tekist vel að halda uppi aga.

Eins og fram hefur komið tengdu viðmælendur gjarna kvenleika við umhyggju og hlýju. Dví pótti forvitnilegt að fá að vita hvort peim fyndist munur á hvernig karlar og konur sýndu umhyggju í kennslunni. Ingi sagði að

karlkennarar væru ... kannski kaldari, eða kannski stífari ... og strangari ... og tilfinningabældari. En pað er kannski bara ímynd ...

Elín nefndi að peir kennslukarlar sem hún pekkti héldu sig í ákveðinni fjarlægð:

Í tilfelli dóttur minnar ... heldur [hann] sér aðeins ... í fjarlægð, meira ... en aðrir kennarar sem hún hefur verið hjá, og pað er ekki endilega neikvætt ... ég er mjög ánægð með hann sem kennara ...

Hún nefndi pessa fjarlægð sem dæmi um mun á umhyggju karla og kvenna; karlar væru fjarlægari en konur sýndu meiri umhyggju. Klara taldi einnig að pað væri munur á pví hvernig kennarar sýndu umhyggju en að munurinn væri meiri pegar börnin væru yngri. Klara var sammála Elínu um að kennslukarlar héldu ákveðinni fjarlægð við kvenkyns nemendur en pessu væri öfugt farið hjá kennslukonunum:

„Eftir pví sem börnin verða eldri ... pá er pað meira gauraspaugilega hliðin hjá karlkyns kennurunum gagnvart strákunum en ... hlédrægni og ,,pú stendur pig vel“ ... pessi, fjarlæga umhyggja frá karlkyns kennurum. Og svolítið svipað nema bara öfugt hjá kvenkyns.“

Enda pótt skoðanir viðmælenda væru ólíkar á pví hvernig nemendur sýndu kennurum virðingu eftir kyni kennaranna og hvernig kennararnir beittu aga eða sýndu umhyggju eftir kyni, kom fram allskýrt mynstur í ólíkum kröfum til kennslukarla og kennslukvenna. Баð kristallast í orðum Elínar: 
En kannski setur maður minni kröfur til karlkyns kennara um að vera góðir í samskiptum. Eða umhyggjusamir ...já, ég held að maður geri ólíkar kröfur.

Afstaðan sem birtist hér í orđum Elínar, sem pó er gagnrýnin á pennan hugsanlega mun á kröfum til kennslukarla og kennslukvenna, er athyglisverð og upplýsandi um mótsagnakennd sjónarmið foreldranna. Viðmælendur vildu gjarna að fleiri karlar gegndu starfi grunnskólakennara og töldu að með pví skapaðist betra jafnvægi í starfinu. En í reynd virðist hætta á pví að sömu kröfur séu ekki gerðar til karla í kennarastarfinu og gerðar eru til kennslukvenna.

\section{Einstaklingshyggja og eðlishyggja}

Degar kafað var ofan í viðtölin kom einstaklingshyggja berlega í ljós í svörum viðmælenda. Einstaklingsmunur virtist skipta meira máli en áhrif kyngervis en annaðhvort var litið fram hjá pví eða pví afneitað. Einstaklingshyggjan kom til dæmis fram hjá viðmælendum í pví að vilja líta á hvern og einn kennara sem einstakling fremur en sem karl eða konu. Ugla sagði:

Maður er orðinn svo barinn til af pessum börnum, sem maður á, að vera ekki kyn, heldur vera einstaklingur ...

Og pegar spurt var um kennslustíl svaraði Ingi að hann héldi að pað væri „,bara rosamikið persónubundið hjá kennaranum sem slíkum ... ég meina, kennari sem nær til nemandans ... er bara flinkur kennari finnst mér ..." Vala tók í sama streng og fannst persónulegir eiginleikar skipta meira máli en kyn. Og Ugla taldi einsýnt að pað færi: „,eftir einstaklingum frekar en kyni. Og líka bara fer eftir krakkanum, hvað hentar hverjum og einum.“

Pótt viðmælendur héldu pví yfirleitt fram að einstaklingsmunur væri almennt meiri en kynjamunur, pá voru, eins og fram hefur komið, sumir eiginleikar engu að síður frekar eignaðir annaðhvort körlum eða konum. Til dæmis héldu Alex, Elín og Ugla pví fram að kennslukonur og kennslukarlar væru að einhverju leyti ólíkar fyrirmyndir. Í pessu felst vitanlega mótsögn við einstaklingshyggjuna.

Viðmælendur voru bersýnilega undir áhrifum viðtekinna hugmynda í orðræðunni um staðalmyndir kynjanna og nauðsyn pess að fjölga körlum í kennslu. Engu að síður vildu peir sjá öðruvísi karlmennskuímyndir en pær hefðbundnu í skólunum. Flestum viðmælendum fannst hugmyndir um karlmennsku vera að breytast til hins betra og peir vildu sjá kennslukarla sem sýndu af sér hlýju.

Sennilega var pessi eðlishyggja ríkari í svörum viðmælenda og kom fram hjá fleiri peirra gagnvart eiginleikum kvenna, eða kvenleikanum, en gagnvart karlmennskunni, sem sumir töldu að væri að breytast. Eðlishyggjan var heldur ekki langt undan í skoðunum á virðingu, aga og umhyggju, pví enda pótt allir viðmælendur teldu bæði konur og karla geta verið góða og umhyggjusama kennara, pá póttu peim pessir eiginleikar frekar vera eðlislægir konum en körlum.

Pá birtist eðlishyggjan í óskum um að hafa bæði karlkyns og kvenkyns kennara starfandi til að endurspegla samfélagið. Pannig taldi Klara að drengir næðu betur að mynda tengsl við karlkyns kennara sína. Hún nefndi einnig að kennslukonur væru almennt ópolinmóðari gagnvart drengjum og væru viðkvæmari fyrir „strákalátum“:

Ef ... allir bekkir væru með tvo kennara, pá ætti einn að vera karl og einn kona [hlær] bara til að endurspegla ... samfélagið. Mín reynsla er að, fyrir strákinn minn, pá hefur honum alltaf gengið betur ef hann hefur haft karlkyns umsjónarkennara, og fundið til meiri tengsla ... Og með kvenkyns kennara finnst mér viðhorfıð peirra til drengja, að pað sé meiri ópolinmæði gagnvart peim heldur en dramatík hjá stelpunum ... Pær eru ... viðkvæmari fyrir svona ,strákalátum“. 
Síðar í viðtalinu sagði Klara pó að eiginleikarnir gætu verið „,pvert á kyn“ en að hún ætti erfitt með að útskýra hvers vegna. Detta má skilja sem svo að eðlishyggjan sé nærtækari leið fyrir foreldrana en mótunarhyggjan, pó svo að í dæmunum hér að framan hafi líka verið örfá dæmi um mótunarhyggju. Enda er eðlishyggjan útbreidd í samfélaginu.

\section{Umræður}

Í greininni er spurt hver séu viðhorf foreldra til kyngervis kennara, hvers konar sjónarmið ráði för og hvort og pá hvaða mótsagnir komi fram. Einnig er spurt hvort rétt sé að leggja áherslu á að fjölga kennslukörlum og pá á hvaða forsendum. Í viðtölum við tíu foreldra komu fram margvísleg viðhorf til karlmennsku og kvenleika og pess hvort kennarar eigi að vera fyrirmyndir 1 samræmi við líffræðilegt kyn. Okkur sýnist að flestir viðmælendur telji að staðalmyndir karlmennskunnar í samfélaginu, en pó einkum í skólunum, séu að breytast. Dannig geti verið æskilegt að kennslukarlar sýni umhyggju fremur en hörku pegar kemur að aga. Detta má flokka undir nýjar gerðir karlmennsku sem stundum eru kenndar við umhyggjukarlmennsku (Elliott, 2016), inngildandi karlmennsku (Andersen, 2009) eða jafnvel við „mjúka menn“ (Goddard, 2000). Viðmælendur tengdu kvenleika pó flestir við hlýju, umhyggju og getuna til að gera margt í einu, sem sannarlega getur komið sér vel í starfi kennara. Fyrri atriðin tengjast hefðbundnum hugmyndum um kvenleika (Warin og Gannerud, 2014) sem „veikan“ eiginleika. Síðasta atriðið, að gera margt í einu, var tengt við hugmyndina um „ofurkonur“ sem ,geta allt“ (Martino og Lauriano, 2013). Hugmyndirnar um að geta gert margt í einu og að sýna umhyggju eru pó hvor tveggja mikilvægir faglegir eiginleikar, sem er óæskilegt að tengja við líffræðilegt kyn kennaranna.

Allir viðmælendur töldu nauðsynlegt að bæði karlar og konur störfuðu í grunnskólum, en af ólíkum ástæðum. Skoðanir peirra viðmælenda sem töldu jafnvægi og fjölbreytni mikilvægast eru í samræmi við pað sem Younger (2016) segir um að umræðan í samfélaginu snúist að miklu leyti um að próa purfi skóla með fjölbreytni í huga. Ingólfur Ásgeir Jóhannesson (2004) hefur einnig talað fyrir pví að pað sem mestu skipti pegar kemur að pví að reyna að fjölga kennslukörlum sé аð með pví sé stuðlað að meiri fjölbreytni innan kennarastéttarinnar fremur en að peir gegni einhverju sjálfstæðu hlutverki sem kynfyrirmyndir.

Nokkrir viðmælendur nefndu líka að kennslukarlar og kennslukonur væru ólíkar fyrirmyndir fyrir nemendur pótt peim reyndist ekki sérlega auðvelt að útskýra á hvaða hátt. Pá var pað helst að nemendur spegluðu sig í kennurum eftir kyni eða samsömuðu sig við sitt líffræðilega kyn. Hjalmarsson og Löfdahl (2014) hafa bent á pversagnir í umræðunni um kyn kennara. Ein pversögnin er sú að litið er á kennarastarfið sem kvenlægt en hins vegar er hæfni kennslukvenna dregin í efa á peim grundvelli að pær geti ekki verið fyrirmyndir fyrir hvaða nemendur sem er, pað er ef til vill ekki fyrir drengina. En kennslukarlar eru síðan boðnir velkomnir par sem peir eiga að bæta upp fyrir pað sem kennslukonur skortir til að vera góðar fyrirmyndir. Viðhorf nokkurra viðmælenda mætti tengja við eðlishyggjusjónarmið sem birtust í pví að peir töldu nauðsynlegt að fjölga kennslukörlum vegna pess að karlmennskufyrirmyndir væru mikilvægar fyrir drengi. Eðlishyggjusjónarmiðið gengur einnig út á pað að drengir tengist kennurum sínum á mismunandi hátt eftir kyni og að kennarar bregðist á mismunandi hátt við nemendum sínum eftir kyni (Skelton, 2012). Detta viðhorf mátti til dæmis finna í svörum Klöru, sem sagði að drengir næðu betri tengslum við kennslukarla og að skilningur kennara á nemendum væri ólíkur eftir kyni. Detta er í samræmi við niðurstöður Brody (2014), en viðmælandi hans sagði að sér fyndist hann ólíkur kennslukonum vegna pess að hann nálgaðist starfið sem karl og pví skildi hann karlkyns nemendur betur.

Degar kom að pví að ræða mun á pví hvort og hvernig nemendur sýndu kennurum sínum virðingu í verki eftir kyni kennaranna komu í ljós ólík viðhorf viðmælenda. Elín nefndi pað að ímynd kennslukonunnar væri of ljúf og að líkamlegir yfirburðir kennslukarla og rödd peirra ykju 
virðingu hjá nemendum. Ingólfur Ásgeir Jóhannesson (2004) hefur bent á að karlmennskan sé oft tengd líkamlegum yfirburðum og voru sjónarmið Elínar í takt við pað. Vísbendingar um að drengir taki síður mark á kennslukonum komu einnig fram í rannsókn Ingólfs Ásgeirs Jóhannessonar (2004) og mætti hugsanlega tengja við pá ímynd kennslukvenna að pær séu góðar og ljúfar konur. Petta er einnig í samræmi við niðurstöður Burn og Pratt-Adams (2015), sem gefa til kynna að dýpri rödd karla og að margir peirra séu hávaxnari en flestar konur, sé talið geta haft áhrif pegar kemur að agastjórnun og virðingu.

Skiptar skoðanir voru einnig á meðal viðmælenda varðandi pað hvort karlar eða konur héldu uppi betri aga í skólastofunni. Jóhann sagðist álíta að körlum gengi betur að halda uppi aga og peir væru strangari. Petta er í takt við niðurstöður Brodys (2014 og Ashcraft og Seviers (2006) par sem viðmælendur töldu að karlar væru betri í agastjórnun en konur og að kyn peirra væri í sjálfu sér fullnægjandi agatæki. Vala var pessu ósammála og sagði að enginn munur væri á agastjórnun karla og kvenna. Dað er í takt við niðurstöður Burn og Pratt-Adams (2015) en par kemur fram að flestir kennslukarlar veigri sér við pví að nota kyn sitt sem agatæki. Detta er líka í samræmi við niðurstöður rannsókna sem benda til pess að pað sem mestu skipti sé hvernig kennari útskýrir námsefnið og að hann komi fram við nemendur af áhuga og virðingu (Ingólfur Ásgeir Jóhannesson, 2004; Skelton, 2012).

Viðmælendur voru að mestu sammála um að munur væri á pví hvernig kennslukarlar og kennslukonur sýndu nemendum umhyggju og nefnt var að karlar héldu ákveðinni fjarlægð við nemendur. Elín var ein peirra sem sagði að kennslukarlar héldu fjarlægð og velti pví fyrir sér hvort hún gerði of litlar kröfur til peirra um umhyggju. Warin og Gannerud (2014) benda á að litið hafi verið á umhyggju við börn sem pátt í eðli konunnar og að konur væru pví sérstaklega vel til pess fallnar að kenna ungum börnum. Warin og Gannerud benda einnig á að körlum leyfist frekar en konum að sýna af sér eins konar kæruleysi pegar kemur að umönnunarstörfum, en pað er í samræmi við upplifun Elínar. Ваð viðhorf að kennslukarlar haldi fjarlægð við nemendur er í samræmi við niðurstöður Sargents (2000), Ashcraft og Seviers (2006) og Brodys (2014). Svör peirra viðmælenda sem töldu að kyn kennara skipti máli pegar kæmi að tengslum við nemendur og varðandi skilning eru einnig í samræmi við niðurstöður Sargents (2000) og Brodys (2014).

Ef petta er dregið saman pá virtist tilhneiging í pá átt að virðing, agi og umhyggja væri tengd kennslukörlum og kennslukonum með ólíkum hætti og er pað í samræmi við niðurstöður Ashcraft og Seviers (2006), Burn og Pratt-Adams (2015) og Sargents (2000). Einnig hafa Hjalmarsson og Löfdahl (2014) bent á að oft mæti kennarar kynjuðum kröfum og væntingum frá foreldrum, nemendum og samstarfsfólki.

Í sjónarmiðum viðmælenda kom vel fram togstreitan milli eðlishyggju og mótunarhyggju en einnig blandað viðhorf, eins og til dæmis hjá Klöru. Alex og fleiri póttu karlmennskufyrirmyndir mikilvægar fyrir nemendur en sérstaklega fyrir drengi. Dessu ber saman við niðurstöður Aschcraft og Seviers (2006), Burn og Pratt-Adams (2015) og Brodys (2014) sem allar sýna að pað sé algengt sjónarmið að nauðsynlegt sé að fjölga körlum í kennslu vegna peirra barna, og pó einkum drengja, sem alast upp hjá einstæðum mæðrum.

Sjónarmiðin sem hér hafa verið rædd eru í flestum tilvikum lituð eðlishyggju. Dau eru líka mótsagnakennd pví að, eins og fram hefur komið, töldu margir viðmælendur, oft peir sömu og ætluðu kennurum kynjaða eiginleika, að einstaklingsmunur væri ekki síður mikill, til dæmis á kennslustíl og framkomu við börnin. Ef eitthvað kom meira á óvart en annað í niðurstöðunum, pá var pað hversu einstaklingshyggjan reyndist rík í orðræðu viðmælenda um leið og peir áttu erfitt með að vera gagnrýnir á kynjaðar staðalmyndir. Ætla má að áherslan á einstaklingsmun sé til marks um afar almennan, ef ekki beinlínis lítinn, skilning á pýðingu kynjajafnréttismála fyrir skólastarfið. 


\section{Lokaorð}

Viðhorf foreldra geta skipt máli pegar kemur að sýn kennara á sjálfa sig og pví er athyglisvert að skoða hvernig kyn kennara hefur áhrif á viðhorfin. Dessi viðhorf reyndust nokkuð mótsagnakennd á köflum en pó voru pau miklu oftar lituð af eðlishyggju en mótunarhyggju. Viðfangsefnið er mikilvægt par sem rannsókn sem pessi hefur ekki verið gerð áður hér á landi og er vonað að hún geti nýst foreldrum til að kanna eigin viðhorf og væntingar til kennara barna sinna. Æskilegt væri að foreldrar ræddu ólíkar hugmyndir og ímyndir um kyngervi við börnin sín.

Ef vilji er fyrir pví að fjölga körlum í grunnskólakennslu, umfram pað að mennta parf fjölda bæði karla og kvenna til starfsins, verður að forðast að gera pað á forsendum sem byggjast á staðalmyndum og hefðbundnum kynhlutverkum. Fjölbreytni í kennarahópi er æskileg en mikilvægt er að ígrunda vel hverjar forsendurnar eru fyrir fjölgun kennslukarla og ætla peim ekki önnur hlutverk en kennslukonunum. Pví parf að huga að pví í kennaramenntun að undirbúa kennaranema af öllum kynjum undir allar hliðar starfsins, par á meðal pá hlið að peir geti, sem nýbrautskráðir kennarar, vænst pess að stundum verði gerðar til peirra ólíkar kröfur eftir kyni. [2]

\section{Athugasemdir}

- Höfundar vita ekki hvort allir kennarar eru annaðhvort karl eða kona og er orðalagið „karlar og konur“ pví notað til einföldunar en ekki til útilokunar á peim kennurum sem skilgreina sig sem hvorki karl né konu.

- Rannsóknin var styrkt af Rannsóknasjóði Háskóla Íslands (Maríanna Jónsdóttir Maríudóttir, 2017).

\section{Teachers' gender in the eyes of parents: Contradictory expectations}

This article explores parents' views towards compulsory school teachers and the way in which the gender of the teachers may or may not influence those views. The study is based on interviews conducted in 2016 and 2017. The interviewees were ten, four men and six women, aged $32-48$ years. Five interviewees were resident in the capital area and five in other regions of the country. Every participant had both a boy and a girl in compulsory school and at least one child in the youngest group (age 6-9) and another one at the intermediate level (age 10-12). It was also a condition that at least one child should have had a male class teacher. In total, the participants had children in six different compulsory schools at the time of the interviews. Thematic analysis was used to analyse the data. The study is based on a poststructuralist view which rejects an essential difference between men and women - thus also a feminist perspective.

The study suggests that teachers' gender is widely discussed among parents, but men and women teachers are not necessarily expected to model the same characteristics. The interviewees' perspectives indicated a conflict between essentialism and constructivism. This was, for example, demonstrated in their views on the importance of children experiencing both genders in diverse roles and also in the views of those who argued that there was a difference between men and women teachers in teaching style and behavior. The interviewees generally claimed that individual differences were greater than gender differences, although a contradiction can be found in the fact that some qualities, nevertheless, were most often attributed to a specific gender. The interviewees found it important that teachers should be good role models for students, but some suggested that men and women teachers might also be different role models. Contrary to what has been reported, the parents often rejected the idea that gender played a role in their views and opted instead for indivi- 
dualism, stating that they did not identify the teachers as men or women but as individuals. The interviewees' attitude largely reflects the social debate about the need to increase the number of men in teaching. The parents did not necessarily want the male teachers to demonstrate traditional masculinity in the classroom; they wanted to see different male role models rather than the traditional ones. Some of them stressed that they wanted a diverse workforce. Most interviewees did not associate the men teachers they knew with hegemonic masculinity, and most, but not all, of the interviewees thought that masculinity was changing for the better and wanted to see teachers who demonstrated warmth. Teachers' gender was not excluded in the debate on respect and discipline. One issue the interviewees mentioned was the possibility that the model of the female teacher was too endearing and that the physical strength of male teachers and their voice might have a positive effect on students' respect for the teacher. The parents all agreed that both men and women could be good and caring teachers. The interviewees mostly agreed that there was a difference between how men and women teachers showed care and most of them said that men teachers maintained a certain distance in their attitude to students, whereas women teachers usually did not. Interviewees' emphasis on individual rather than gender difference is likely to be indicative of a rather limited and general understanding of the importance of gender equality in schools.

The researchers want to underline that if a specific strategy to increase the number of men teachers in compulsory schools is introduced, it must be critical of stereotypes based on traditional gender roles. Furthermore, that teacher education must prepare student teachers of all genders for all aspects of the teacher's job, including the probability that gendered expectations may await them when they begin working.

Keywords: Teachers' gender, compulsory school teachers, parents' views, teachers' role

\section{Um höfundana}

Maríanna Jónsdóttir Maríudóttir (mariannaj@vidistadaskóli.is) er umsjónarkennari við Víðistaðaskóla. Hún lauk BA-prófi í listfræði frá Íslensku- og menningardeild Háskóla Íslands 2015 og meistaraprófi í kennslufræði grunnskóla frá Kennaradeild Háskóla Íslands 2018. Rannsóknaráhugi hennar snýr einkum að kynjajafnrétti í skólastarfi. Dessi grein var skrifuð sem hluti af meistaraprófsverkefni Maríönnu.

Ingólfur Ásgeir Jóhannesson (ingo@hi.is) er prófessor við Menntavísindasvið Háskóla Íslands. Hann lauk BA-prófi í sagnfræði 1979, prófi í uppeldis- og kennslufræði til kennsluréttinda 1980, cand.mag.-prófi í sagnfræði 1983 frá Háskóla Íslands og doktorsprófi í menntunarfræðum frá Wisconsin-háskóla, Madison, 1991. Rannsóknir Ingólfs eru einkum á sviði námskrár, menntastefnu og kynjajafnréttis í skólastarfi.

\footnotetext{
About the authors

Maríanna Jónsdóttir Maríudóttir (mariannaj@vidistadaskóli.is) is a teacher in the compulsory school Víðistaðaskóli in Hafnarfjörður. She completed a BA degree in Art History and Theory as a major in the Faculty of Icelandic and Comparative Cultural Studies at the University of Iceland in 2015 and a master's degree in compulsory school teaching from the Faculty of Teacher Education, University of Iceland in 2018. Her research interest is in gender and education. This article is based on her master's thesis.
} 
Ingólfur Ásgeir Jóhannesson (ingo@hi.is) is a professor at the University of Iceland, School of Education. He completed BA and cand.mag. degrees in history in 1979 and 1983, respectively, a postgraduate teaching certification diploma from the University of Iceland in 1980, and a $\mathrm{PhD}$ in curriculum and instruction from the University of Wisconsin, Madison in 1991. His research areas include curriculum, education policy, and gender and education.

\section{Heimildir}

(Athuga: Höfundar óska eftir pví í femínískum anda að fá að hafa eiginnöfn erlendra höfunda í stað upphafsstafa.)

Andersen, Eric. (2009). Inclusive masculinity. The changing nature of masculinities. New York: Routledge.

Ashcraft, Katherine og Sevier, Brian. (2006). Gender will find a way: Exploring how male elementary teachers make sense of their experiences and responsibilities. Contemporary Issues in Early Childhood, 7(2), 130-145. doi: org/10.2304/ ciec.2006.7.2.130

Brody, David. (2014). Men who teach young children, an international perspective. London: Institute of Education.

Burn, Elizabeth og Pratt-Adams, Simon. (2015). Men teaching children 3-11. Dismantling gender barriers. London: Bloomsbury Academic.

Connell, Raewyn. (2006). Understanding men: Gender sociology and the new international research on masculinities. Í Christine Skelton, Becky Francis og Lisa Smulyan (ritstjórar), The SAGE handbook on gender and education (bls. 18-31). London: Sage.

Connell, Raewyn og Messerschmidt, James. (2005). Hegemonic masculinity: Rethinking the concept. Gender \& Society, 19(6), 829-859. doi: 10.1177/0891243205278639

Elliott, Karla. (2016). Caring masculinities: Theorizing an emerging concept. Men and Masculinities, 19(3), 240-259. doi: $10.1177 / 1097184 X 15576203$

Goddard, Kevin. (2000). "Looks maketh the man": The female gaze and the construction of masculinity. Journal of Men's Studies, 9(1), 23-39. doi: pdf/10.3149/jms.0901.23

Guðný Guðbjörnsdóttir. (2007). Menntun, forysta og kynferði. Reykjavík: Háskólaútgáfan.

Gyða Margrét Pétursdóttir. (2012). Styðjandi og mengandi kvenleiki innan áru kynjajafnréttis. Íslenska pjóðfélagið, 3, 5-18.

Hagstofa Íslands. (2015). Starfffólk í grunnskólum eftir starfssviðum og kyni 1998-2014. Sótt af https://www.hagstofa.is/

Hjalmarsson, Maria og Löfdahl, Annica. (2014). Being caring and disciplinary - male primary school teachers on expectations from others. Gender and Education, 26(3), 280-292. doi: org/10.1080/09540253.2014.901731

Ingólfur Ásgeir Jóhannesson. (1992). Af vettvangi íslenskra menntaumbóta. Kennarafræði sem kapítal. Uppeldi og menntun, $1,147-164$.

Ingólfur Ásgeir Jóhannesson. (2004). Karlmennska og jafnéttisuppeldi. Reykjavík: Rannsóknastofa í kvenna区 og kynjafræðum við Háskóla Íslands.

Ingólfur Ásgeir Jóhannesson. (2006). To be a male role model—or to be a teacher: Notes on the discourse about men primary teachers in Iceland. Norma - Nordic Journal for Masculinity Studies, 1(1), 82-95.

Lichtman, Marilyn. (2013). Qualitative research in education: a user's guide. Los Angeles, London: Sage.

Loftur Guttormsson. (2008). Fræðsluhefðin: kirkjuleg heimafræðsla. Í Loftur Guttormsson (ritstjóri), Almenningsfreðsla á Íslandi, (fyrra bindi, bls. 23-35). Reykjavík: Háskólaútgáfan.

Maríanna Jónsdóttir Maríudóttir. (2017). Foreldrar grunnskólabarna vilja fjölbreytni í kennarahópnum (meistaraprófsritgerð). Háskóli Íslands, Menntavísindasvið.

Martino, Sara og Lauriano, Shaelene. (2013). Feminist identity and the superwoman ideal. Journal of Behavioral Health, 2(2), 167-172. doi: 10.5455/jbh.20130224082826

Menntamálaráđuneytið. (2002). Menntun fyrir alla. Yfirlýsing sett fram á albjóðaráđstefnu UNESCO í Dakar árið 2000. Reykjavík: Menntamálaráđuneytið.

Rannveig Traustadóttir. (2013). Femínískar rannsóknir. Í Sigríður Halldórsdóttir (ritstýra), Handbók í ađferđafraði rannsókna (bls. 313-327). Akureyri: Háskólinn á Akureyri.

Sargent, Paul. (2000). Real men or real teachers? Contradictions in the lives of men elementary teachers. Men and Masculinities, 2(4), 410-433. doi: org/10.1177/1097184X00002004003 
Schippers, Mimi. (2007). Recovering the feminine other: Masculinity, femininity, and gender hegemony. Theory, Culture \& Society, 36(1), 85--102.

Skelton, Christine. (2012). Men teachers and the "feminised" primary school: a review of the literature. Educational Review, 64(1), 1-19. doi: org/10.1080/00131911.2011.616634

Sternod, Brandon M. (2011). Role models or normalizing agents? A genealogical analysis of popular written news media discourse regarding male teachers. Curriculum Inquiry, 41(2), 267-292. doi: org/10.1111/j.1467.873X.2011.00545.x

Warin, Jo og Gannerud, Eva. (2014). Gender, teaching and care: a comparative global conversation. Gender and Education, 26(3), 193-199. doi: org/10.1080/09540253.2014.928023

Wernersson, Inga. (2016). More men? Swedish arguments over four decades about 'missing men' in ECE and care. Í Simon Brownhill, Jo Warin og Inga Wernersson (ritstjórar), Men, masculinities and teaching in early education: international perspectives on gender and care (bls. 13-26). London: Routledge.

Younger, Mike. (2016). Foreword. Í Simon Brownhill, Jo Warin og Inga Wernersson (ritstjórar), Men, masculinities and teaching in early education: international perspectives on gender and care (bls. xiii-xv). London: Routledge.

Pórdís Pórðardóttir. (2005). Hvers vegna á kynjafræði erindi í kennarafræðimenntun? Í Arna H. Jónsdóttir, Steinunn H. Lárusdóttir og Dórdís Dórðardóttir (ritstýrur), Kynjamyndir í skólastarfi (bls. 31-52). Reykjavík: Rannsóknarstofnun Kennaraháskóla Íslands.

Dórdís Dórðardóttir. (2012). „Flugfreyjur koma með matinn en stýra ekki sjálfar.“ Kvenleiki, karlmennska og störf í samræðum ungra barna. Í Jóhanna Einarsdóttir og Bryndís Garðarsdóttir (ritstjórar), Raddir barna (bls. 134-162). Reykjavík: Háskólaútgáfan.

Maríanna Jónsdóttir Maríudóttir og Ingólfur Ásgeir Jóhannesson. (2018).

Kyngervi kennara í augum foreldra: Mótsagnakenndar kröfur

Netla - Veftímarit um uppeldi og menntun. Menntavísindasvið Háskóla Íslands.

Sótt af http://netla.hi.is/greinar/2018/ryn/06

DOI: https://doi.org/10.24270/netla.2018.6 